\title{
Maternal bronchial carcinoma and its possible relation to neonatal hypoglycaemia
}

\author{
J. C. Sharp \\ M.B., Ch.B., M.R.C.P.(U.K.), D.C.H. \\ M. J. CARTY \\ M.B., Ch.B., F.R.C.S.E., M.R.C.O.G.
}

\author{
R. W. LOGAN \\ M.B., Ch.B., B.Sc., M.R.C.Path. \\ Royal Hospital for Sick Children \\ and the Queen Mother's Hospital, Glasgow
}

\section{Summary}

A neonate whose mother had been diagnosed as suffering from bronchial carcinoma presented with many of the features characterizing the syndrome shown by babies of diabetic mothers. It is suggested that over-production of corticotrophin in the mother was responsible for the hypoglycaemia and other manifestations in the infant.

\section{Introduction}

It is well known that pregnancy is associated with an increase in plasma cortisol and that especially in the third trimester the values attained resemble a state of adrenocortical hyperfunction (Kopelman \& Levitz, 1970). It has also been shown that the concentration of cortisol in cord blood reflects the maternal state although it is less than the corresponding maternal values and is also influenced by neonatal adrenal activity. Following delivery, plasma cortisol levels in infants fall as the maternal contribution disappears from the circulation and values from 3 to 7 days following birth reflect endogenous neonatal adrenocortical activity. The predisposition of infants of prediabetic or frankly diabetic mothers to develop hypoglycaemia has also been well documented. This is presumed to be due to a temporary beta-cell hyperplasia induced in the foetal islets by the maternal hyperglycaemia. Limited observations made on such infants have indicated that where normal sugar concentrations exist, cortisol concentration tends to be compensatorily elevated.

\section{Case history}

The mother, who had suffered from dyspnoea during pregnancy, was shown 6 weeks before parturition to have a lesion diagnosed radiologically as a carcinoma of the right main bronchus. The tumour was considered to be inoperable.
The baby was born prematurely, by spontaneous vaginal delivery, on 31 October 1970 at 34 weeks gestation. The Apgar score at $2 \mathrm{~min}$ was 5 and the birth weight was $3.49 \mathrm{~kg}$ ( $>97$ th centile). Hydramnios was observed and, because of oedema, the mother was given frusemide, $(40 \mathrm{mg} \times 2)$ in the first $24 \mathrm{hr}$ following delivery. Cyanosis and respiratory distress were present initially in the neonate although there had been neither maternal pyrexia nor evidence of foetal distress. The initial respiratory acidosis with $\mathrm{PCO}_{2}$ of $68 \mathrm{mmHg}$ had resolved by $8 \mathrm{hr}$ when the $\mathrm{PCO}_{2}$ was $40 \mathrm{mmHg}$, the baby having been nursed in an incubator with moderate oxygen concentrations. The chest X-ray was compatible with pulmonary oedema. Clinically, the baby appeared to be of 38 weeks' gestation and was oedematous. At $13 \mathrm{hr}$, hypoglycaemia developed, the baby having been 'twittery' with a faint Dextrostix reading. True glucose was less than $5 \mathrm{mg} / 100 \mathrm{ml}$. Treatment followed the normal pattern with intravenous dextrose being given for $48 \mathrm{hr}$ without complication. At $48 \mathrm{hr}$ the baby was also quite markedly icteric and serum indirect bilirubin rose to a maximum of $23 \mathrm{mg} / 100 \mathrm{ml}$ by day 5 , before falling. The infant remained 'fragile' for some time, tending to become cyanosed on handling, and weight loss continued until the eleventh day, after which time the infant steadily improved until discharge on day 14 .

\section{Methods and results}

Investigations were undertaken in the mother and child to determine cortisol status and, in the case of the mother, glucose handling. Plasma 11-hydroxycorticoids ('cortisol') were determined using a micromodification of the procedure of Mattingly (1962), requiring only $0.2 \mathrm{ml}$ plasma. Blood glucose was measured using a specific glucose oxidase procedure known to be virtually free from interference by other 
carbohydrate and non-carbohydrate-reducing substances including glutathione. Urinary 17-oxosteroid and total 17-oxogenic steroid excretions were estimated by the MRC recommended methods (Medical Research Council, 1969), and the cortisol secretion rate by an isotope dilution procedure similar to that described by Cope \& Black (1958). On the fourth day at $09.45 \mathrm{hr}$, the child had a subnormal plasma cortisol of less than $5 \mu \mathrm{g} / 100 \mathrm{ml}$ which showed a low normal increment rising to $22 \mu \mathrm{g} / 100 \mathrm{ml} 1 \mathrm{hr}$ after $50 \mu \mathrm{g}$ Synacthen had been given intramuscularly. On day 7 at $09.30 \mathrm{hr}$, the plasma cortisol was within normal limits at $18 \mu \mathrm{g} /$ $100 \mathrm{ml}$. The mother on day 4 at $09.30 \mathrm{hr}$ had a plasma cortisol of $80 \mu \mathrm{g} / 100 \mathrm{ml}$ which was considered to be elevated. On day 13 her cortisol was $45 \mu \mathrm{g} / 100 \mathrm{ml}$ at $21.30 \mathrm{hr}$ and the following morning at $10.30 \mathrm{hr}$ it was $42 \mu \mathrm{g} / 100 \mathrm{ml}$, both of which values were considered to be above normal.

A standard glucose tolerance test was performed, administering $50 \mathrm{~g}$ of glucose orally 11 days postpartum. The blood sugar concentrations during the test were $94,135,164$ and $128 \mathrm{mg} / 100 \mathrm{ml}$ at 0,30 , 60 and $120 \mathrm{~min}$ respectively. The $2 \mathrm{hr}$ value was suspiciously high. A course of radiotherapy commenced 11 days post-partum, lasted 21 days (i.e. 11 November 1970 to 2 December 1970) and resulted in marked clinical and radiological improvement. The biochemical results obtained shortly after completion of the radiotherapy are shown in Table 1. The cortisol secretion rate on 3-4 December 1970 was normal at $16 \mathrm{mg} / 24 \mathrm{hr}$. All the results in Table 1 were considered to be within normal limits with the exception of the diurnal variation in plasma cortisol which is not so marked as would be expected in normal circumstances. A glucose tolerance test repeated on 15 December 1970 also yielded normal results of $65,120,140,110$ and $75 \mathrm{mg} / 100 \mathrm{ml}$ at 0 , $30,60,90$ and $120 \mathrm{~min}$. Loss of diurnal rhythm in plasma cortisol recurred, $4 \frac{1}{2}$ months post-partum, concentrations of $28 \mu \mathrm{g} / 100 \mathrm{ml}$ and $26 \mu \mathrm{g} / 100 \mathrm{ml}$ being found at $09.30 \mathrm{hr}$ and $20.30 \mathrm{hr}$. At that time the patient was complaining of paraesthesiae affecting both legs. Subsequently the clinical condition improved and values reverted to normal $-20 \mu \mathrm{g} /$ $100 \mathrm{ml}$ and $9 \mu \mathrm{g} / 100 \mathrm{ml}$ at 10.00 and $16.20 \mathrm{hr}$. The baby remains well.

\section{Discussion}

Using the method described, one of us (R.W.L.) has derived a normal range for plasma 'cortisol' concentrations before and $1 \mathrm{hr}$ after administration of $50 \mu \mathrm{g}$ Synacthen to infants 1,3 and 5-7 days following birth. So too, an attempt has been made to define normal limits for maternal plasma cortisol concentrations at various times prior to and following delivery. These results have been used in interpreting the present findings and are shown in Table 2.

The salient features in the case described are the state of maternal hyperadrenocorticism and disturbed glucose tolerance which persisted until the course of radiotherapy, and the neonatal hypoglycaemia associated with the appearance of a large baby of a diabetic mother. Diabetes or prediabetes in the mother could have explained the child's Cushingoid appearance and the subsequent hypoglycaemia but would not be sufficient alone to account for the subnormal plasma cortisol observed in the infant. On the contrary, an infant of such a diabetic mother exhibited a plasma cortisol of $64 \mu \mathrm{g} / 100 \mathrm{ml}$ during a hypoglycaemic episode. So too, the relative hyperadrenocorticism of pregnancy is insufficient to explain the findings, the present maternal cortisol values being above the established ranges, and that of the infant prior to Synacthen being below the lower normal limits.

It is postulated, therefore, that an over-production of corticotrophin in the mother would account for all the manifestations. The maternal plasma cortisol concentration would be elevated and this would tend to impair carbohydrate tolerance whilst also crossing the placenta and producing temporary pituitary/ adrenocortical suppression in the infant. The likelihood that maternal glucose concentrations would

TABLE 1. Urine and plasma steroid results following radiotherapy

\begin{tabular}{|c|c|c|c|c|c|c|c|}
\hline \multirow[b]{2}{*}{ Date } & \multirow[b]{2}{*}{ Procedure } & \multicolumn{4}{|c|}{ Urine } & \multicolumn{2}{|c|}{ Plasma } \\
\hline & & $\begin{array}{l}\text { Volume } \\
\text { (ml) }\end{array}$ & $\begin{array}{l}\text { Creatinine } \\
\text { (mg) }\end{array}$ & $\begin{array}{l}\text { 17-oxosteroids } \\
\text { (mg) }\end{array}$ & $\begin{array}{l}\text { 17-oxogenic } \\
\text { steroids (mg) }\end{array}$ & Time & $\begin{array}{l}\text { 11-hydroxy- } \\
\text { corticoids } \\
(\mu \mathrm{g} / 100 \mathrm{ml})\end{array}$ \\
\hline \multicolumn{8}{|c|}{$\begin{array}{l}\text { December } \\
1970\end{array}$} \\
\hline $3-4$ & ${ }^{3} \mathbf{H}$ cortisol orally & 765 & 1025 & 6 & 8 & $10.30 \mathrm{hr}$ & 22 \\
\hline $4-5$ & $\begin{array}{l}\text { Dexamethasone } \\
(0.5 \mathrm{mg} \text { q.i.d. })\end{array}$ & 560 & 930 & 3 & 5 & - & - \\
\hline $5-6$ & $\begin{array}{l}\text { Dexamethasone } \\
(0.5 \mathrm{mg} \text { q.i.d. })\end{array}$ & 880 & 818 & 2 & 2 & $\begin{array}{l}10.30 \mathrm{hr} \\
22.30 \mathrm{hr}\end{array}$ & $\begin{array}{r}8 \\
16\end{array}$ \\
\hline $6-7$ & $\begin{array}{l}\text { Dexamethasone } \\
(2.0 \mathrm{mg} \text { q.i.d) }\end{array}$ & - & - & - & - & - & - \\
\hline $7-8$ & $\begin{array}{l}\text { Dexamethasone } \\
(2.0 \mathrm{mg} \text { q.i.d. })\end{array}$ & 1020 & 867 & 2 & 2 & $10.00 \mathrm{hr}$ & 5 \\
\hline
\end{tabular}


TABLE 2. Maternal and neonatal plasma 11-hydroxycorticoids 'Cortisol' concentrations $(\mu \mathrm{g} / 100 \mathrm{ml})$

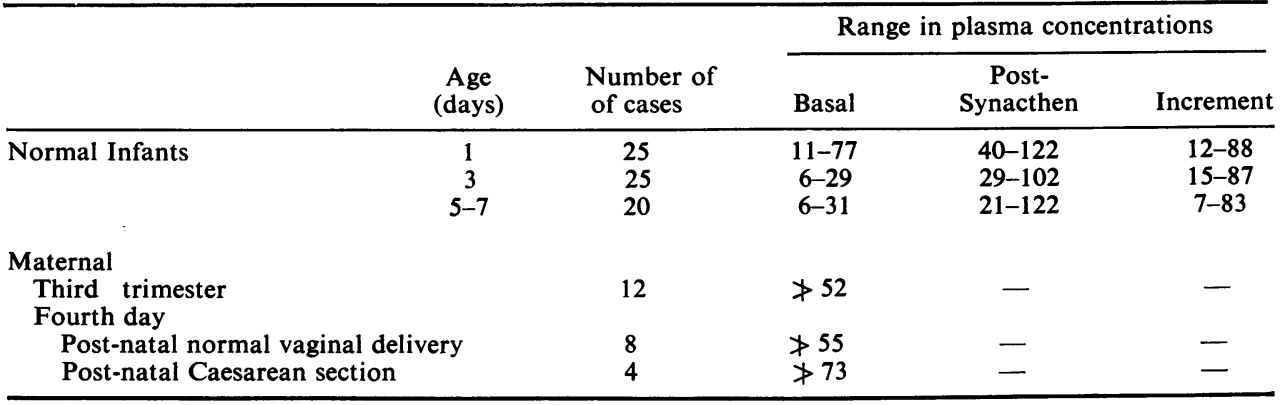

be greater than normal would also result in temporary beta-cell hyperplasia in the infant. The neonatal hypoglycaemia and adrenocortical insufficiency already demonstrated would be not unexpected. So too, the premature labour could possibly be explained by the increased corticotrophin production which has been noted to have such an action in sheep although similar evidence in human subjects is less well documented.

There is, however, some doubt as to the origin of the possible excess corticotrophin in the mother. Ectopic corticotrophin-producing tumours are associated with clinical features which were absent in this case, and the response following radiotherapy is usually poor. Another explanation in the present case is that the stress caused by the bronchial carcinoma induced an increase in the output of normal pituitary corticotrophin. This would also account for the observations and would perhaps be easier to reconcile with the restoration of clinical and biochemical normality following treatment. In any event, the patient is being seen at regular intervals, morning and evening plasma cortisol concentrations being monitored in an attempt to detect a possible recurrence of the condition. Estimations of plasma corticotrophin will be performed if elevated cortisol values are detected.

\section{Acknowledgments}

We should like to thank Professor J. H. Hutchison, Dr M. M. Kerr and Dr J. Willocks for their assistance and permission to publish this case and Dr J. K. Grant for the estimation of the urinary steriod excretions and cortisol secretion rate. Thanks are also due to $\mathrm{Dr} T$. B. Binns of Ciba Laboratories for the generous gift of the Synacthen used by $\mathbf{R}$. W. L. in assessing adrenocortical function in normal neonates.

\section{References}

COPE, C.L. \& BLACK, E.G. (1958) The behaviour of C14. cortisol and estimations of cortisol production in man. Clinical Science, 17, 147.

Kopelman, J.J. \& Levitz, M. (1970) Plasma cortisol levels and cortisol binding in normal and pre-eclamptic pregnancies. American Journal of Obstetrics and Gynecology, $108,925$.

MatTingly, D. (1962) A simple fluorimetric method for the estimation of free 11-hydroxycorticoids in human plasma. Journal of Clinical Pathology, 15, 374.

Medical Research Council Committee on Clinical EndoCRINOLOGY (1969) A critical appraisal of a method of estimating urinary 17-oxosteroids and total 17-oxogenic steroids. Lancet, i, 124.

\title{
Recovery from severe paraquat poisoning
}

\author{
D. B. Galloway \\ M.R.C.P.
}

\section{J. C. Petrie M.R.C.P.}

Department of Therapeutics and Clinical Pharmacology, University of Aberdeen

Summary

Recovery from poisoning with the herbicide, paraquat ( $20 \%$ concentrate-'Gramoxone') is rare (Malone $e t$ $e l .$, 1971). A patient is reported who survived despite ingesting an apparently fatal dose. Treatment consisted of forced diuresis and a single haemodialysis. Oxygen, steroids and immunosuppressives were not given. 